\title{
Adenosine and maximum coronary vasodilation in humans: myth and misconceptions in the assessment of coronary reserve
}

\author{
Gerd Heusch
}

Published online: 26 November 2009

(C) Springer-Verlag 2009

In the heart, the purine nucleoside adenosine acts on heart rate, contractile function and coronary blood flow. Adenosine acts as a negative chronotrope in the sinoatrial and atrioventricular nodes and in atrial myocytes through adenosine $A_{1}$ receptor activation [43, 45]. Adenosine acts as a negative inotrope, largely through its anti-adrenergic action after adenosine $A_{1}$ receptor activation [43]. Adenosine acts as a coronary dilator, largely through activation of adenosine $\mathrm{A}_{2 \mathrm{~A}}$ receptors $[43,45]$. In humans, arteriolar dilation in response to adenosine is mediated by $\mathrm{A}_{2 \mathrm{~A}}$ receptors, adenylate cyclase and calcium-activated potassium channels in vascular smooth muscle cells [52]. Also, indirect effects contribute to the role of adenosine in coronary blood flow: adenosine inhibits presynaptic release of norepinephrine from sympathetic nerves [43], inhibits platelet aggregation [35] and inhibits leukocyte adherence to the vascular wall [59]. $A_{1}$ receptors are coupled to $G_{i / o}$ proteins and their activation decreases cAMP, whereas $A_{2 A}$ receptors are coupled to $\mathrm{G}_{\mathrm{s}}$ proteins and mediate an increase in cAMP [1, 43].

Endogenous adenosine is an autacoid which is released with increases in heart rate and ventricular function during sympathetic activation. Originally, adenosine was proposed to be the substance which, through its coronary dilator action, served to mediate metabolic coronary regulation, i.e. the matching of coronary blood flow to the energetic requirements of the contracting myocardium [6, 17]. This original idea of adenosine as the mediator of metabolic coronary blood flow regulation was attractive, because

G. Heusch $(\bowtie)$

Institut für Pathophysiologie, Universitätsklinikum Essen,

Hufelandstr. 55, 45122 Essen, Germany

e-mail: gerd.heusch@uk-essen.de adenosine is a catabolite of ATP, and thus could provide a stoichiometric coupling of energy demand and supply. Today, we have come to realize that cardiac adenosine metabolism is much more complex. In addition to the production of adenosine in cardiomyocytes, significant fractions of adenosine are continuously formed in the endothelium and at extracellular sites [12]. Adenosine is only one out of a number of redundant mechanisms which provide metabolic regulation of coronary blood flow, together with nitric oxide, activation of ATP-dependent K-channels and others [3, 13, 15]. During myocardial ischemia and reperfusion, adenosine is an important trigger and mediator of cardioprotection through activation of adenosine $A_{1}, A_{2 B}$ and $A_{3}$ receptors $[1,11,28]$. Adenosine is also an algesic substance and involved in pain sensation during myocardial ischemia [58]; finally, adenosine attenuates left ventricular hypertrophy [55]. Thus, adenosine serves as a general feed-back mediator in the heart, certainly during pathological circumstances such as hypertrophy, hypoxia and ischemia and possibly also under physiological circumstances, e.g. by inhibition of the interaction of leukocytes with the endothelium.

Apart from its use to suppress supraventricular tachycardia, exogenous adenosine is used in patients with coronary heart disease mainly for two puposes: (a) to determine coronary reserve, and (b) to induce a maldistribution of myocardial blood flow into areas with persistent dilator reserve at the expense of areas with pre-existing compensatory vasodilation and thus reduced dilator reserve, i.e. a collateral and/or transmural steal [56, 61] and to image such maldistribution [7]. For the latter purpose, i.e. pharmacological stress testing, it is not important whether adenosine causes truly maximal coronary dilation as long as it acts as a powerful dilator. For the determination of coronary reserve, however, the assessment of true 
maximal coronary dilation is essential, and here is where myth and misconceptions exist.

The angiographic assessment of luminal diameter provides only incomplete information on the functional severity of a coronary stenosis, particularly with intermediate stenoses. To better estimate the importance of a coronary stenosis for myocardial perfusion, clinicians have taken resort to what they call "coronary physiology" [34]. The coronary pressure-flow relationship, which is determined in experiments in dogs and pigs at stepwise variations of pressure and/or flow, best characterizes coronary hemodynamics [8, 20, 23, 42, 54, 57] (Fig. 1): There is a zero flow-pressure intercept, i.e. coronary blood flow ceases at a perfusion pressure of about $20 \mathrm{mmHg}$; in the beating heart, both capacitance and inertial effects with storage of blood volume in epicardial vessels during systole and its discharge into subendocardial vessels during diastole contribute to such zero flow-pressure intercept. Under physiological circumstances, coronary blood flow then almost linearly increases when pressure increases from the zero flow-pressure intercept to about 40$50 \mathrm{mmHg}$. With further increasing pressure, autoregulation dampens any further increase in coronary blood flow such that in a range of pressures from 70 to $130 \mathrm{mmHg}$ coronary blood flow is largely pressure-independent. The level of this autoregulatory plateau is set by myocardial performance and metabolism, i.e. coronary blood flow is higher with higher metabolism and vice versa [42] (dashed lines in Fig. 1). With a hypothetical maximal dilation, i.e. elimination of any active vasomotor tone, autoregulation is abolished and coronary blood flow is, at any pressure above the zero flow-pressure intercept, linearly related to perfusion pressure; in fact, since the coronary vasculature is not

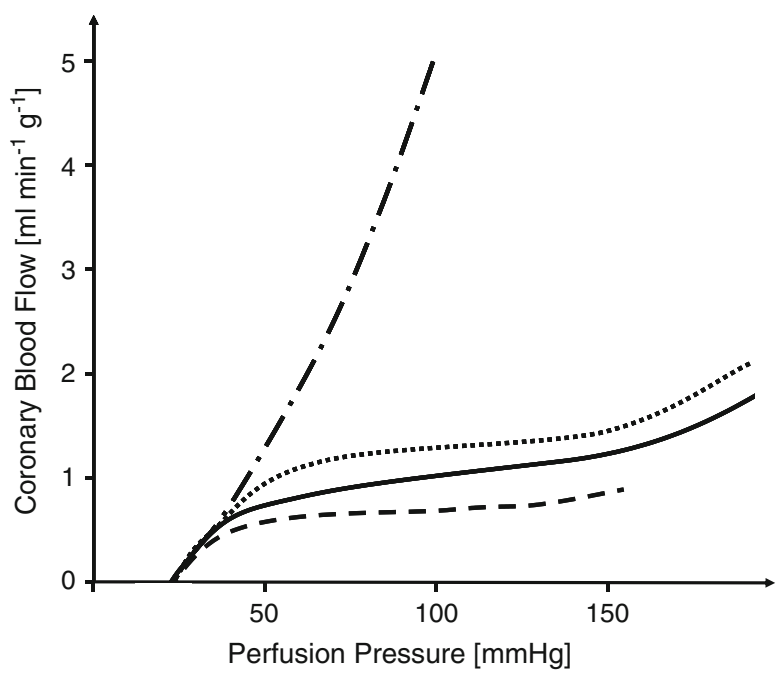

Fig. 1 Coronary pressure-flow relationship. The curves are not hypothetical, but synthetized from original data in Refs. [2, 8, 20, 42, $54,57]$, all in dog or pig hearts a rigid tube but distensible, the relation is even slightly concave away from the pressure axis. The pressure-flow relationship does not characterize the instantaneous relation of flow and pressure within a cardiac cycle but mean values of both flow and pressure during a hemodynamic steady state.

It is clearly not feasible to generate a pressure-flow relationship in patients with coronary heart disease. The concept of coronary reserve condenses a major part of the information provided by the pressure-flow relationship into a single numerical value; coronary reserve is the dimensionless ratio of maximal coronary blood flow over baseline coronary blood flow $[10,18,19]$. A closer look at the pressure-flow relationship (Fig. 1) immediately identifies two problems of the coronary reserve concept: (a) the ratio of maximal over baseline coronary blood flow depends on perfusion pressure, and (b) baseline coronary blood flow and therefore also the ratio depends on myocardial performance and metabolism-notably on heart rate [41] as the single most important determinant of myocardial metabolism[26]. Attempts to correct for pressure and heart rate have therefore been made, by calculating resistances according to Ohm's law (mean pressure/mean flow) [36], by relating coronary reserve to the pressure-rate product [62], or by normalizing coronary reserve in the vessel under study to a purportedly normal reference vessel in the same individual (relative coronary reserve) [4]. These attempts for correction, in turn, have problems: pressure and flow are not linearly related throughout and do not pass through the origin; therefore Ohm's law is not really applicable. The error introduced by the use of Ohm's law is the greater, the lower perfusion pressure and the closer it is to the zero flow-pressure intercept, i.e. in the presence of coronary stenoses. The pressure-rate product is only an incomplete estimate of myocardial metabolism and assumes homogeneous conditions throughout the entire heart. However, in coronary heart disease myocardial function, metabolism and perfusion are heterogeneous, and regions with normal flow and function co-exist with regions which have matched or mismatched reductions in flow and function [24, 32]. Substitution of the pressure-rate product would therefore not provide a valid estimate for regional myocardial metabolism, particularly not in poststenotic myocardium. In a patient undergoing invasive diagnostics for coronary heart disease the existence of an entirely normal vessel is unlikely, since even the presence of a risk factor is already associated with impaired coronary vasodilation [66, 67].

Notwithstanding the above limitations, the concept of coronary reserve relies on maximal coronary vasodilation, i.e. the elimination of all active coronary vasomotor tone, and then assumes that flow at any given pressure is solely determined by the morphology of the coronary vascular 
bed and by extravascular compression [3, 49], which is again largely determined by diastolic duration and thus heart rate $[33,51]$.

Is adenosine or any other dilator substance indeed capable of eliminating all active vasomotor tone? Increases in coronary blood flow from about $1 \mathrm{ml} \mathrm{min}^{-1} \mathrm{~g}^{-1}$ at baseline up to $5 \mathrm{ml} \mathrm{min} \mathrm{m}^{-1} \mathrm{~g}^{-1}$, i.e. a coronary reserve up to 5 , with individual values exceeding 8 , have been reported using intracoronary Doppler flow measurements in patients with normal coronary angiography undergoing invasive diagnostics for chest pain [65] and in normal volunteers using positron emission tomography [9]. When using Doppler measurements of coronary blood flow velocity only, coronary reserve is probably somewhat underestimated, since a small additional epicardial coronary dilation is neglected. Intracoronary Doppler data are not available from true normals, since there has always been a history of chest pain, and even the presence of a risk factor is associated with impaired vasodilation [66, 67]. Also, a thorough exclusion of atherosclerosis by intravascular ultrasound in the patients with normal coronary angiograms [16] is missing in most studies. Therefore, the highest reported values for maximal coronary blood flow and coronary reserve come most likely closest to true physiological values, since all confounding factors tend to induce an underestimation of maximal coronary blood flow. To assure that indeed a maximum increment in coronary blood flow is recorded, incremental doses of adenosine must be given, and ultimately a lack of further flow increase with an additional dose of adenosine documented [65]; this is only rarely done in clinical diagnostics $[14,44]$, and mostly standard adenosine doses are given, normalized for coronary artery perfusion territory on intracoronary use or for body weight on intravenous use [34]. Adenosine has a fair selectivity for the coronary circulation, but at systemic doses aiming for maximal coronary vasodilation, hypotension and reflex tachycardia are inevitable, both of which impair the coronary blood flow response. Also, the algesic action of adenosine may limit its use at higher doses in some patients. On the other hand, the use of adenosine is safe, since it is rapidly eliminated from the vascular space by uptake into erythrocytes and endothelium [12].

Even high-dose adenosine does not eliminate all coronary vasomotor tone. $\alpha$-Adrenergic coronary vasoconstriction is not eliminated in the experiment [30], and coronary reserve in humans is limited by both $\alpha_{1}$-adrenergic and $\alpha_{2}$-adrenergic coronary vasoconstriction $[5,21$, $27,39,50]$. The limitation of coronary reserve by $\alpha$ adrenergic coronary vasoconstriction is particularly important with coronary atherosclerosis [5] and during percutaneous coronary interventions [21, 22]. In the experiment, adenosine is also not capable to eliminate endothelin-induced coronary vasoconstriction [38], and it is unclear to which other coronary vasoconstrictors (angiotensin, serotonin [37], thromboxane A2 [37], vasopressin) the inability of adenosine to fully eliminate vasoconstriction pertains.

Are there alternatives to adenosine to induce maximal coronary dilation? Reactive hyperemia responses following 20 -s coronary occlusion resulted in a coronary velocity reserve value of 5.8 in patients undergoing cardiac surgery but with normal coronary angiograms [40]; this mean value appears to be somewhat higher than those reported for adenosine. Dipyridamole, which inhibits the nucleoside transporter in cell membranes and then potentiates the action of endogenous adenosine [53], induces a coronary dilation of similar magnitude as that by adenosine in the "normal" coronary circulation $[9,63,64]$. The same is true for intracoronary papaverine $[41,64,65]$, but papaverine induces undesired EKG abnormalities [34]. In a thorough study with definition of normal coronary status not only by angiography but also by intravascular ultrasound, intracoronary papaverine recruited a coronary reserve of 5.3 [16]. Intracoronary nitroprusside caused equivalent coronary vasodilation to adenosine, yet at pre-existing subnormal coronary reserve [46]. In the experiment, dihydropyridine calcium antagonists can eliminate $\alpha$-adrenergic coronary vasoconstriction [29] and still recruit a dilator reserve in ischemic myocardium [31], but their negative inotropic action might limit their use in the clinical assessment of coronary reserve.

Notwithstanding all of the above critical considerations and limitations, coronary reserve assessment using standard doses of adenosine and with cut-off values substantially below normal values, often below 3 , provides important prognostic information and reasonably guides clinical decisions on coronary interventions [25, 34]. The concept of fractional flow reserve entirely relies on the use of Ohm's law and is solely based on coronary pressure rather than flow measurements to assess coronary dilator capacity [48]; despite thus being even further away from the physiology of the coronary pressure-flow relationship, fractional flow reserve assessment is more easily feasible and empirically validated to provide prognostic information $[47,60]$.

In summary, to identify and contradict the most frequent misconceptions: (1) Adenosine is not the predominant mediator of physiological regulation of coronary blood flow. (2) Adenosine does not eliminate all active coronary vasomotor tone. (3) Coronary reserve is not independent of hemodynamics, notably arterial pressure and heart rate. (4) A coronary reserve of 3 is not normal. Thus, the physiological assessment of coronary reserve with adenosine is really a myth: it has a true core which is overshadowed by layers of pragmatic compromises, and just because this myth is so often told, truth and fiction are often no longer 
distinguished in daily practice. In conclusion, I am not opposing empirically founded standard use of adenosine and coronary reserve cut-off values as low as 2.7 for pragmatic clinical decision-making, but I want to raise the awareness that such procedure is far away from coronary physiology.

Acknowledgment Professors Andreas Deussen and Rainer Schulz critically read this editorial.

\section{References}

1. Auchampach JA, Bolli R (1999) Adenosine receptor subtypes in the heart: therapeutic opportunities and challenges. Am J Physiol 276:H1113-H1116

2. Aversano T, Becker LC (1985) Persistence of coronary vasodilator reserve despite functionally significant flow reduction. Am J Physiol 248:H403-H411

3. Bassenge E, Heusch G (1990) Endothelial and neuro-humoral control of coronary blood flow in health and disease. Rev Physiol Biochem Pharmacol 116:77-165

4. Baumgart D, Haude M, Goerge G, Ge J, Vetter S, Dagres N, Heusch G, Erbel R (1998) Improved assessment of coronary stenosis severity using the relative flow velocity reserve. Circulation 98:40-46

5. Baumgart D, Haude M, Goerge G, Liu F, Ge J, Große-Eggebrecht C, Erbel R, Heusch G (1999) Augmented $\alpha$-adrenergic constriction of atherosclerotic human coronary arteries. Circulation 99:2090-2097

6. Berne RM (1963) Cardiac nucleotides in hypoxia: possible role in regulation of coronary blood flow. Am J Physiol 204:317-322

7. Botvinick EH (2009) Current methods of pharmacologic stress testing and the potential advantages of new agents. J Nucl Med Technol 37:14-25

8. Canty JM, Klocke FJ (1985) Reduced regional myocardial perfusion in the presence of pharmacologic vasodilator reserve. Circulation 71:370-377

9. Chan SY, Brunken RC, Czernin J, Porenta G, Kuhle W, Krivokapich J, Phelps ME, Schelbert HR (1992) Comparison of maximal myocardial blood flow during adenosine infusion with that of intravenous dipyridamole in normal men. J Am Coll Cardiol 20:979-985

10. Coffman JD, Gregg DE (1960) Reactive hyperemia characteristics of the myocardium. Am J Physiol 199:1143-1149

11. Cohen MV, Downey JM (2008) Adenosine: trigger and mediator of cardioprotection. Basic Res Cardiol 103:203-215

12. Deussen A (2001) Metabolic flux rates of adenosine in the heart. Naunyn Schmiedebergs Arch Pharmacol 362:351-363

13. Deussen A, Brand M, Pexa A, Weichsel J (2006) Metabolic coronary flow regulation-current concepts. Basic Res Cardiol 101:453-464

14. di Segni E, Higano ST, Rihal CS, Holmes DR Jr, Lennon R, Lerman A (2001) Incremental doses of intracoronary adenosine for the assessment of coronary velocity reserve for clinical decision making. Catheter Cardiovasc Interv 54:34-40

15. Duncker DJ, Bache RJ (2008) Regulation of coronary blood flow during exercise. Physiol Rev 88:1009-1086

16. Erbel R, Ge J, Bockisch A, Kearney P, Görge G, Haude M, Schümann D, Zamorano J, Rupprecht HJ, Meyer J (1996) Value of intracoronary ultrasound and doppler in the differentiation of angiographically normal coronary arteries: a prospective study in patients with angina pectoris. Eur Heart J 17:880-889
17. Gerlach E, Deuticke B, Dreisbach RH (1963) Der NucleotidAbbau im Herzmuskel bei Sauerstoffmangel und seine mögliche Bedeutung für die Coronardurchblutung. Naturwissenschaften 6:228-229

18. Gould KL, Kirkeeide RL, Buchi M (1990) Coronary flow reserve as a physiologic measure of stenosis severity. J Am Coll Cardiol 15:459-474

19. Gould KL, Lipscomb K (1974) Effects of coronary stenoses on coronary flow reserve and resistance. Am J Cardiol 34:48-55

20. Grattan MT, Hanley FL, Stevens MB, Hoffman JIE (1986) Transmural coronary flow reserve patterns in dogs. Am J Physiol 250:H276-H283

21. Gregorini L, Marco J, Farah B, Bernies M, Palombo C, Kozakova M, Bossi IM, Cassagneau B, Fajadet J, Di Mario C, Albiero R, Cugno M, Grossi A, Heusch G (2002) Effects of selective $\alpha_{1}$ - and $\alpha_{2}$-adrenergic blockade on coronary flow reserve after coronary stenting. Circulation 106:2901-2907

22. Gregorini L, Marco J, Kozàkovà M, Palombo C, Anguissola GB, Marco I, Bernies M, Cassagneau B, Distante A, Bossi IM, Fajadet J, Heusch G (1999) Alpha-adrenergic blockade improves recovery of myocardial perfusion and function after coronary stenting in patients with acute myocardial infarction. Circulation 99: 482-490

23. Gross GJ, Farber NE, Hardman HF, Warltier DC (1986) Beneficial actions of superoxide dismutase and catalase in stunned myocardium of dogs. Am J Physiol 250:H372-H377

24. Guth BD, Schulz R, Heusch G (1993) Time course and mechanisms of contractile dysfunction during acute myocardial ischemia. Circulation 87(Suppl IV):IV-35-IV-42

25. Haude M, Baumgart D, Verna E, Piek JJ, Vrints C, Probst P, Erbel R (2001) Intracoronary doppler- and quantitative coronary angiography-derived predictors of major adverse cardiac events after stent implantation. Circulation 103:1212-1217

26. Heusch G (2008) Heart rate in the pathophysiology of coronary blood flow and myocardial ischaemia: benefit from selective bradycardic agents. Br J Pharmacol 153:1589-1610

27. Heusch G, Baumgart D, Camici P, Chilian W, Gregorini L, Hess O, Indolfi C, Rimoldi O (2000) $\alpha$-Adrenergic coronary vasoconstriction and myocardial ischemia in humans. Circulation 101:689-694

28. Heusch G, Boengler K, Schulz R (2008) Cardioprotection: nitric oxide, protein kinases, and mitochondria. Circulation 118:19151919

29. Heusch G, Deussen A (1984) Nifedipine prevents sympathetic vasoconstriction distal to severe coronary stenoses. J Cardiovasc Pharmacol 6:378-383

30. Heusch G, Deussen A, Schipke J, Thämer V (1986) Adenosine, dipyridamole and isosorbiddinitrate are ineffective to prevent the sympathetic initiation of poststenotic myocardial ischemia. Drug Res 36:1045-1048

31. Heusch G, Guth BD, Seitelberger R, Ross J Jr (1987) Attenuation of exercise-induced myocardial ischemia in dogs with recruitment of coronary vasodilator reserve by nifedipine. Circulation 75:482-490

32. Heusch G, Schulz R, Rahimtoola SH (2005) Myocardial hibernation: a delicate balance. Am J Physiol Heart Circ Physiol 288:H984-H999

33. Heusch G, Yoshimoto N (1983) Effects of heart rate and perfusion pressure on segmental coronary resistances and collateral perfusion. Pflügers Arch 397:284-289

34. Kern MJ, Lerman A, Bech JW, De BB, Eeckhout E, Fearon WF, Higano ST, Lim MJ, Meuwissen M, Piek JJ, Pijls NH, Siebes M, Spaan JA (2006) Physiological assessment of coronary artery disease in the cardiac catheterization laboratory: a scientific statement from the American Heart Association Committee on 
Diagnostic and Interventional Cardiac Catheterization, Council on Clinical Cardiology. Circulation 114:1321-1341

35. Kitakaze M, Hori M, Sato H, Takashima S, Inoue M, Kitabatake A, Kamada T (1991) Endogenous adenosine inhibits platelet aggregation during myocardial ischemia in dogs. Circ Res 69:1402-1408

36. Knaapen P, Camici PG, Marques KM, Nijveldt R, Bax JJ, Westerhof N, Gotte MJ, Jerosch-Herold M, Schelbert HR, Lammertsma AA, van Rossum AC (2009) Coronary microvascular resistance: methods for its quantification in humans. Basic Res Cardiol 104:485-498

37. Leineweber K, Böse D, Vogelsang M, Haude M, Erbel R, Heusch $G$ (2006) Intense vasoconstriction in response to aspirate from stented saphenous vein aortocoronary bypass grafts. J Am Coll Cardiol 47:981-986

38. Loghin C, Sdringola S, Gould KL (2007) Does coronary vasodilation after adenosine override endothelin-1-induced coronary vasoconstriction? Am J Physiol Heart Circ Physiol 292:H496$\mathrm{H} 502$

39. Lorenzoni R, Rosen SD, Camici PG (1996) Effect of $\alpha_{1}$-adrenoceptor blockade on resting and hyperemic myocardial blood flow in normal humans. Am J Physiol Heart Circ Physiol 271:H1302-H1306

40. Marcus ML, Wright C, Doty D, Eastham C, Laughlin D, Krumm P, Fastenow C, Brody M (1981) Measurements of coronary velocity and reactive hyperemia in the coronary circulation of humans. Circ Res 49:877-891

41. McGinn AL, White CW, Wilson RF (1990) Interstudy variability of coronary flow reserve. Influence of heart rate, arterial pressure, and ventricular preload. Circulation 81:1319-1330

42. Mosher P, Ross J Jr, McFate PA, Shaw RF (1964) Control of coronary blood flow by an autoregulatory mechanism. Circ Res 14:250-259

43. Mubagwa K, Mullane K, Flameng W (1996) Role of adenosine in the heart and circulation. Cardiovasc Res 32:797-813

44. Murtagh B, Higano S, Lennon R, Mathew V, Holmes DR Jr, Lerman A (2003) Role of incremental doses of intracoronary adenosine for fractional flow reserve assessment. Am Heart J 146:99-105

45. Mustafa SJ, Morrison RR, Teng B, Pelleg A (2009) Adenosine receptors and the heart: role in regulation of coronary blood flow and cardiac electrophysiology. Handb Exp Pharmacol (193): 161-188

46. Parham WA, Bouhasin A, Ciaramita JP, Khoukaz S, Herrmann SC, Kern MJ (2004) Coronary hyperemic dose responses of intracoronary sodium nitroprusside. Circulation 109:1236-1243

47. Pijls NHJ, de Bruyne B, Peels K, van der Voort PH, Bonnier HJRM, Bartunek J, Koolen JJ (1996) Measurement of fractional flow reserve to assess the functional severity of coronary-artery stensoses. N Engl J Med 334:1703-1708

48. Pijls NHJ, Van Gelder B, van der Voort P, Peels K, Bracke FALE, Bonnier HJRM, El Gamal MIH (1995) Fractional flow reserve. A useful index to evaluate the influence of an epicardial coronary stenosis on myocardial blood flow. Circulation 92: 3183-3193

49. Raff WK, Kosche F, Lochner W (1972) Extravascular coronary resistance and its relation to microcirculation. Am J Cardiol 29:598-603

50. Rimoldi O, Spyrou N, Foale R, Hackett DR, Gregorini L, Camici PG (2000) Limitation of coronary reserve after successful angioplasty is prevented by oral pretreatment with an $\alpha_{1}$-adrenergic antagonist. J Cardiovasc Pharmacol 36:310-315
51. Rossen JD, Winniford MD (1993) Effect of increases in heart rate and arterial pressure on coronary flow reserve in humans. J Am Coll Cardiol 21:343-348

52. Sato A, Terata K, Miura H, Toyama K, FRJr Loberiza, Hatoum OA, Saito T, Sakuma I, Gutterman DD (2005) Mechanism of vasodilation to adenosine in coronary arterioles from patients with heart disease. Am J Physiol Heart Circ Physiol 288:H1633H1640

53. Schaper W (2005) Dipyridamole, an underestimated vascular protective drug. Cardiovasc Drugs Ther 19:357-363

54. Schulz R, Guth BD, Heusch G (1991) No effect of coronary perfusion on regional myocardial function within the autoregulatory range in pigs: evidence against the Gregg phenomenon. Circulation 83:1390-1403

55. Schulz R, Heusch G (2008) Extracellular adenosine attenuates left ventricular hypertrophy through its impact on the protein kinase and phosphatase interaction. Hypertension 51:1474-1475

56. Seiler C, Fleisch M, Meier B (1997) Direct intracoronary evidence of collateral steal in humans. Circulation 96:4261-4267

57. Shaw RF, Mosher P, Ross J Jr, Joseph JI, Lee AS (1962) Physiologic principles of coronary perfusion. $\mathrm{J}$ Thorac Cardiovasc Surg 44:608-616

58. Sylven C (1993) Mechanisms of pain in angina pectoris-a critical review of the adenosine hypothesis. Cardiovasc Drugs Ther 7:745-759

59. Todd J, Zhao Z-Q, Williams MW, Sato H, Van Wylen DGL, Vinten-Johansen J (1996) Intravascular adenosine at reperfusion reduces infarct size and neutrophil adherence. Ann Thorac Surg 62:1364-1372

60. Tonino PA, De BB, Pijls NH, Siebert U, Ikeno F, Veer M, Klauss V, Manoharan G, Engstrom T, Oldroyd KG, Ver Lee PN, MacCarthy PA, Fearon WF (2009) Fractional flow reserve versus angiography for guiding percutaneous coronary intervention. $\mathrm{N}$ Engl J Med 360:213-224

61. Werner GS, Fritzenwanger M, Prochnau D, Schwarz G, Ferrari M, Aarnoudse W, Pijls NHJ, Figullla HR (2006) Determinants of coronary steal in chronic total coronary occlusions. Donor artery, collateral, and microvascular resistance. J Am Coll Cardiol 48:51-58

62. Wieneke H, von Birgelen C, Haude M, Eggebrecht H, Möhlenkamp S, Schmermund A, Böse D, Altmann C, Bartel T, Erbel R (2005) Determinants of coronary blood flow in humans: quantification by intracoronary Doppler ultrasound. J Appl Physiol 98:1076-1082

63. Wilson RF, Laughlin DE, Ackell PH, Chilian WM, Holida MD, Hartley CJ, Armstrong ML, Marcus ML, White CW (1985) Transluminal, subselective measurement of coronary artery blood flow velocity and vasodilator reserve in man. Circulation 72:82-92

64. Wilson RF, White CW (1986) Intracoronary papaverine: an ideal coronary vasodilator for studies of the coronary circulation in conscious humans. Circulation 73:444-451

65. Wilson RF, Wyche K, Christensen BV, Zimmer S, Laxson DD (1990) Effects of adenosine on human coronary arterial circulation. Circulation 82:1595-1606

66. Zeiher AM, Drexler H, Saurbier B, Just H (1993) Endotheliummediated coronary blood flow modulation in humans. Effects of age, atherosclerosis, hypercholesterolemia, and hypertension. J Clin Invest 92:652-662

67. Zeiher AM, Drexler H, Wollschläger H, Just H (1991) Endothelial dysfunction of the coronary microvasculature is associated with impaired coronary blood flow regulation in patients with early atherosclerosis. Circulation 84:1-10 